\title{
Possible Nonpathogenic Origin of Hydrangea. Distortion
}

\author{
Douglas A. Bailey ${ }^{1}$ and P. Allen Hammer ${ }^{2}$ \\ Department of Horticulture, Purdue University, West Lafayette, IN 47907
}

Additional index words. Hydrangea macrophylla, temperature stress, viruses, mycoplasma-like organisms

Florists' hydrangea, Hydrangea macrophylla subsp. macrophylla var. macrophylla (Thunb.) Ser., is susceptible to a foliar malformation that appears during high day temperature $(>30 \mathrm{C})$ periods of summer production. This condition previously has been termed hydrangea distortion (Weiler and Lopes, 1974). Affected plants produce thickened laminae that are sometimes mottled and reduced in width (Fig. 1). The plant apex becomes irregularly shortened, distorted apices often produce abnormal inflorescences, and many of the affected plants do not flower. In many respects, the symptoms of hydrangea distortion are similar to symptoms expressed by plants infected with a virus. Hydrangeas are known to be susceptible to nine viruses: alfalfa mosaic, cucumber mosaic, hydrangea ringspot, tobacco necrosis, tobacco rattle, tobacco ringspot, tomato ringspot, and tomato spotted wilt virus. A mycoplasma-like organism (MLO) also has been identified within hydrangeas (Kleinhempel et al., 1972; Lawson and Smith, 1980). The etiology of hydrangea distortion has not been described, and we therefore examined the possibility of a viral or MLO origin of this problem.

Virus indicator plant species (Catharanthus roseus 'Dwarf Bright Eyes', Chenopodium amaranticolor, Chenopodium quinoa, Cucumis sativus, Gomphrena globosa 'Buddy Purple', Lycopersicon esculentum 'Rutgers', Nicotiana clevelandii, Nicotiana glutinosa, Nicotiana tabacum 'Samsun NN', Phaseolus vulgaris 'Bountiful', and Vigna sinensis 'Early Ramshorn') were inoculated with sap from distorted foliage of $H$. macrophylla 'Rose Supreme' or 'Merritt's Supreme'. Inoculum was prepared by grinding distorted leaves in

Received for publication 12 Dec. 1988. Journal paper no. 10,984 of the Purdue Univ. Agricultural Experiment Station. This research was funded in part by a grant from the Fred C. Gloeckner Foundation and is from a thesis submitted by D.A.B. in partial fulfillment of the requirements for the PhD degree. Thanks to the Dept. of Botany and Plant Pathology, Purdue Univ., for their assistance and to the Dept. of Plant Pathology, Cornell Univ., for the transmission electron microscope work. The cost of publishing this paper was defrayed in part by the payment of page charges. Under postal regulations, this paper therefore must be hereby marked advertisement solely to indicate this fact.

'Assistant Professor. Current address: Dept. of Horticultural Science, North Carolina State Univ., Box 7609, Raleigh, NC 27695.

${ }^{2}$ Professor of Horticulture.
0.01 м phosphate buffer, $\mathrm{pH}$ 7.0. Three plants of each species were either untreated, inoculated with buffer, or inoculated with sap. No symptoms of virus infection were evident after 10 weeks on any of the indicator plants during the experiment, regardless of the inoculum source.

Three plants each of $H$. macrophyla 'Blau Donau' and 'Tricolor', nondistorting cultivars, were untreated, inoculated with buffer, or inoculated with sap. from distorted leaves of 'Rose Supreme'. Treated plants were placed in environmental conditions conducive to formation of distortion symptoms.' Bailey and Hammer, 1989) for 8 weeks. Three plants of 'Rose Supreme' lacking distortion symptoms also were placed within the growth chamber to ensure the effectiveness of the screening environment. No plants of 'Blau Donau' or 'Tricolor' expressed distortion symptoms during the period following inoculation. All 'Rose Supreme' plants had distorted foliage by the end of week 5 .

Virus-indexed plants (Allen et al., 1984) of 'Rose Supreme' were acquired from two independent sources, for testing of hydrangea distortion susceptibility. All 10 plants had distorted foliage by the end of week 4 in the distortion-inducing environment.

Malformed leaves were removed from plants of 'Rose Supreme' that were grown in the distortion-inducing environment for 8 weeks and samples were examined under a transmission electron microscope. Sap from distorted leaves was examined for virus particles, MLOs, and. inclusion bodies using negative staining and leaf dip techniques. No virus particles were detected on any of the grids examined. No foreign inclusion bodies were present, and the stained sap solution appeared normal. The examined sap was void of pleomorphic and helical particles associated with MLO infection.

Rooted terminal cuttings of $H$. macrophylla 'Rosa Rita', hydroponically grown for 3 weeks in a $22 / 26 \mathrm{C}$ (minimum/venting) greenhouse under $16-\mathrm{hr}$ photoperiods were placed in the distortion-inducing environment. Hydroponic solutions of three plants were unamended; amended with $12.5 \mathrm{mg}$ penicillin $\mathrm{G}, 10 \mathrm{mg}$ oxytetracycline, and 5 $\mathrm{mg}$ tetracycline-hydrochloride/liter; or amended with $2.5 \mathrm{mg}$ penicillin $\mathrm{G}, 20 \mathrm{mg}$ oxytetracycline, and $10 \mathrm{mg}$ tetracycline hydrochloride/liter. The solution of each plant was changed weekly for 8 weeks. Antibiotic sprays were also applied to 'Rose Supreme' grown in the distortion-inducing environment for 8 weeks before treatment. Three plants each were sprayed with $1.5 \mathrm{ml}$ of either $0.01 \mathrm{M}$ phosphate buffer ( $\mathrm{pH} 7.0$ ) or with buffer amended with $100 \mathrm{mg}$ oxytetracycline plus $100 \mathrm{mg}$ tetracycline hydrochloride/liter every 3 days for 7 weeks. The antibiotic treatments applied within the hydroponic solution were extremely phytotoxic and all treated plants had died after 4 weeks, but no plants produced distorted foliage before death. Control plants did not produce distorted foliage until week 6 . The foliar application of antibiotics had no effect on hydrangea distortion symptoms and plants continued to produce distorted leaves 7 weeks after start of treatment. The plants receiving antibiotic sprays had slight foliar chlorosis after week 3.

We have concluded from these experiments that distortion is likely nonpathogenic in origin and nontransmittable. These results indirectly support our hypothesis (Bailey and Hammer, 1989) that the distortion is strictly physiological and its expression is a genotypic/environment interaction.

\section{Literature Cited}

Allen, T.C., J.P. McMorran, and R.H. Lawson 1984. Detection and identification of viruses in hydrangea. Acta Hort. 164:85-90.

Bailey, D.A. and P.A. Hammer. 1989. Stimulation of "hydrangea distortion" through environmental manipulations. J. Amer. Soc. Hort. Sci. 114:411-416.

Kleinhempel, H., H.M. Muller, and D. Spaar. 1972. Mögliche mykoplasmaätiologie von Pflanzenkrankheiten. Nachrichtenblatt für den Pflanzenschutzdienst in der DDR. 26(12):1-3.

Lawson, R.H. and F.F. Smith. 1980. Hydrangea virescence: Symptom suppression in plants infected with mycoplasma-like organism (MLO) associated with mild disease challenge infected with the severe disease MLO. Acta Hort. 110:329-334.

Weiler, T.C. and L.C. Lopes. 1974. Hydrangea distortion. Focus on Floriculture, Purdue Univ., W. Lafayette, Ind. 2(2):9.

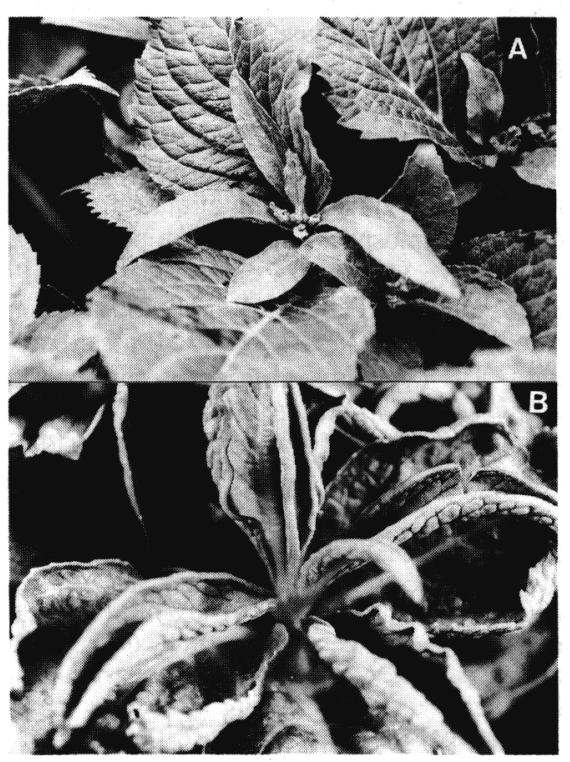

Fig. 1. Symptoms of hydrangea distortion on $H$. macrophylla 'Rose Supreme' growing outdoors (A) or in the distortion-inducing environment within a growth chamber (B). 